\title{
Strength and Leaching Behavior of Contaminated Mining Sludge at High Water Content Stabilized with Lime Activated GGBS
}

\author{
Traore Abdoul Fatah, Rongjun Zhang, Xiaosong Huang *(D), Junjie Zheng, Yu Miao and Aamir Khan Mastoi $\mathbb{D}$ \\ Institute of Geotechnical and Underground Engineering, Huazhong University of Science and Technology, \\ Wuhan 430074, China; abdoulfatah@hust.edu.cn (T.A.F.); ce_zhangrj@hust.edu.cn (R.Z.); \\ zhengjj@hust.edu.cn (J.Z.); miaoyu@hust.edu.cn (Y.M.); ak.mastoi21@gmail.com (A.K.M.) \\ * Correspondence: huangxs@hust.edu.cn
}

Citation: Abdoul Fatah, T.; Zhang, R.; Huang, X.; Zheng, J.; Miao, Y.;

Mastoi, A.K. Strength and Leaching Behavior of Contaminated Mining Sludge at High Water Content Stabilized with Lime Activated GGBS. Materials 2021, 14, 6524. https:// doi.org/10.3390/ma14216524

Academic Editor: Sabino De Gisi

Received: 15 September 2021

Accepted: 26 October 2021

Published: 29 October 2021

Publisher's Note: MDPI stays neutral with regard to jurisdictional claims in published maps and institutional affiliations.

Copyright: (C) 2021 by the authors. Licensee MDPI, Basel, Switzerland. This article is an open access article distributed under the terms and conditions of the Creative Commons Attribution (CC BY) license (https:/ / creativecommons.org/licenses/by/ $4.0 /)$.

\begin{abstract}
Sludge management is one of the major challenges in mining activities. The direct disposal of contaminated mining sludge can bring severe damages to the environment and community. Solidification/stabilization (S/S) is a very efficient technology for the treatment of contaminated mining sludge because it improves the stability of sludge dumping sites and reduces the leachability of contaminants. Very few studies investigate the S/S of mining sludge, especially with high water content. This paper investigated the effectiveness of $S / S$ for the treatment of mining sludge at high water content by using quick lime $(\mathrm{CaO})$ activated ground granulated blast furnace slag (GGBS) in comparison to ordinary Portland cement (OPC). To evaluate the mechanical, leaching, and microstructural behavior of CMS at high water content stabilized by lime-activated GGBS and OPC, a series of laboratory experimental tests were performed. Experimental results indicated that increasing the dosage of binder led to increased strength and decreased leachability of the heavy metal. In contrast, an increase in the water content of the mixture resulted in a decrease in compressive strength and an increase in the leachability of heavy metals. On the other hand, lime-activated GGBS mixes had substantially better performance than OPC mixes in the aspect of strength development of treated mining sludge and showed comparable capability of heavy metal stabilization compared to OPC. The microstructural tests revealed the formation of different hydration products such as calcium silicate hydrate, calcium aluminum silicate hydrate, ettringite, hydrotalcite, and heavy metal complexes in CG and OPC mixes.
\end{abstract}

Keywords: mining sludge; solidification/stabilization; cement; ground granulated blast furnace slag; strength; heavy metal leachability

\section{Introduction}

Mining activities are essential in the economic development of many countries over the world. The extraction of minerals presents opportunities, challenges, and risks to sustainable development. Mining exploitation often leads to environmental and ecological challenges, such as soil and underwater pollution in mining areas, plant destruction and biodiversity loss, and geological and land destruction. The most widely used contaminated mining sludge disposal method is pond disposal. However, the disposal of heavy metal contaminated mining sludge (CMS) at high-water content could cause significant environmental and ecological damages [1]. Furthermore, the tailings dam collapse caused environmental and natural disasters that can have severe consequences of loss of life, environmental and financial consequences in billions of dollars [2]. Therefore, the effective remediation of a high water content CMS has drawn the interest of researchers worldwide.

There are many remediation techniques available to treat such high water content CMS to avoid environmental pollution. However, the Solidification/stabilization (S/S) treatment method is attractive for many wastes, including CMS, by utilizing cement, 
lime, and other binders to minimize the toxicity of contaminants and enhance mechanical strength before final disposal [3]. Solidification/stabilization is one of the most applied technology to improve sludge stability [4] and is a very recognized technique for the treatment of heavy metal contaminated soils [5]. After mixing the binder with the sludge, the binders react with heavy metal salts and form precipitations (i.e., compounds or insoluble complex hydroxides) due to their alkaline nature [6]. Furthermore, the heavy metals are encapsulated by hydration products such as calcium silicate hydrate (CSH), calcium aluminate hydrate $(\mathrm{CAH})$ generated during the hydration process [7].

However, because the manufacturing of cement and lime is very often associated with enormous energy consumption and generates very high carbon dioxide emissions in the environment [8], researchers have recently been attempting to develop an ecofriendly alternative for these conventional binders in recent years with the intention of using industrial waste such as ground granulated blast furnace slag (GGBS). GGBS is a by-product of the steel industry, and its production requires low energy consumption and carbon emission [9]. It is an eco-friendly binder for engineering projects and can substitute or partially replace cement or lime in soil treatment [10]. Several researchers studied the solidification/stabilization of heavy metal contaminated soils using GGBS [11]. The results suggested that activated GGBS could effectively improve the mechanical properties of contaminated soils and avoid the leaching of the contaminant into the environment [12].

Nevertheless, without an activator, GGBS cannot completely react with the soil particles. In fact, in the S/S process, the strength of the matrices containing only GGBS is generally lower than that of the samples containing activated GGBS, which indicates that the presence of an activator can considerably improve the mechanical behavior of the GGBS system [13] and reduce the leachability of heavy metal. The type of activator has a considerable impact on the resistance of treated soils [14]. Generally, cement and lime are common activators used in the GGBS system [15]. In the case of GGBS, calcium hydroxide $\mathrm{Ca}(\mathrm{OH})_{2}$ and calcium oxide $(\mathrm{CaO})$ are effective activators because they are readily available and significantly less expensive than other activators such as OPC, sodium silicate, and sodium hydroxide [16]. Comparing the effect of $\mathrm{CaO}$ and $\mathrm{Ca}(\mathrm{OH})_{2}$ on GGBS activation revealed that $\mathrm{CaO}$ had a greater mechanical strength and activation potential for GGBS than $\mathrm{Ca}(\mathrm{OH})_{2}$ [17]. Some recent studies also demonstrated that GGBS activated by reactive magnesia $(\mathrm{MgO})$ with a perfect ratio led to a higher UCS than OPC or GGBS-CaO blends [18]. However, the application of MgO-GGBS in soil treatment remains limited because the cost of magnesia-activated GGBS in the treatment of soil is more expensive than lime [16]. Using lime as an activator of GGBS in soil treatment can be a way to cut down the total cost of treatment.

To date, very few studies investigated the effects of lime-activated GGBS, on the solidification/stabilization process of mining sludge, especially with high water content. This study aims to gain an insight into the strength characteristics and heavy metal leaching behavior of contaminated mining sludge at high water content solidified/stabilized with lime-activated GGBS or OPC. It considers the leachability of three contaminants, $\mathrm{Cu}$, $\mathrm{Pb}$, and $\mathrm{Zn}$, which are among the commonly encountered heavy metals in the soil [19]. In fact, $\mathrm{Cu}, \mathrm{Pb}$, and $\mathrm{Zn}$ rank amongst the fifth heavy metal in the industrial production of metal [20], and they represent the most common heavy metals found at contaminated sites [21]. $\mathrm{Pb}, \mathrm{Cu}$, and $\mathrm{Zn}$ are significant because they have the potential to reduce crop output due to bioaccumulation and biomagnification in the food chain, the possibility of contamination of soil, groundwater, vegetation, and air pollution, and resulting ecological environmental diseases during the processing of mining operations [22].

Microstructural characteristics were also investigated through X-ray diffraction (XRD) and scanning electron microscopy (SEM) to better understand the change in strength (constitution). 


\section{Material and Method}

\subsection{Materials}

Contaminated sludge used in the laboratory experiments was collected from an actual copper mine site. As summarized in Table 1, basic physiochemical characteristics of the used sludge were determined according to China Standard GB/T 50123-2019, "Standard for geotechnical testing". The particle size distribution is shown in Figure 1, and concentrations of heavy metals $(\mathrm{Cu}, \mathrm{Pb}$, and $\mathrm{Zn})$ were tested using flame atomic absorption spectrometry and presented in Table 1.

Table 1. Physical properties of the mining sludge collected from the actual copper mine site.

\begin{tabular}{|c|c|}
\hline Property & Value \\
\hline Nature moisture content, $\%$ & 50 \\
\hline $\mathrm{pH}$ & 7.8 \\
\hline Specific gravity & 2.61 \\
\hline Liquid limit LL, \% & 41.45 \\
\hline Plastic limit PL, \% & 24.43 \\
\hline Plasticity Index & 17.02 \\
\hline Sand fraction $(0.075-2 \mathrm{~mm}), \%$ & 1.68 \\
\hline Silt fraction $(0.002-0.075 \mathrm{~mm}), \%$ & 79.74 \\
\hline Clay and colloid fraction $(<0.002 \mathrm{~mm}), \%$ & 18.58 \\
\hline Soil Classification & Lean clay CL \\
\hline Total $\mathrm{Cu}$ concentration, $\mathrm{mg} / \mathrm{kg}$ & 609.92 \\
\hline Total $\mathrm{Pb}$ concentration, $\mathrm{mg} / \mathrm{kg}$ & 15.6 \\
\hline Total $\mathrm{Zn}$ concentration, $\mathrm{mg} / \mathrm{kg}$ & 274.9 \\
\hline
\end{tabular}

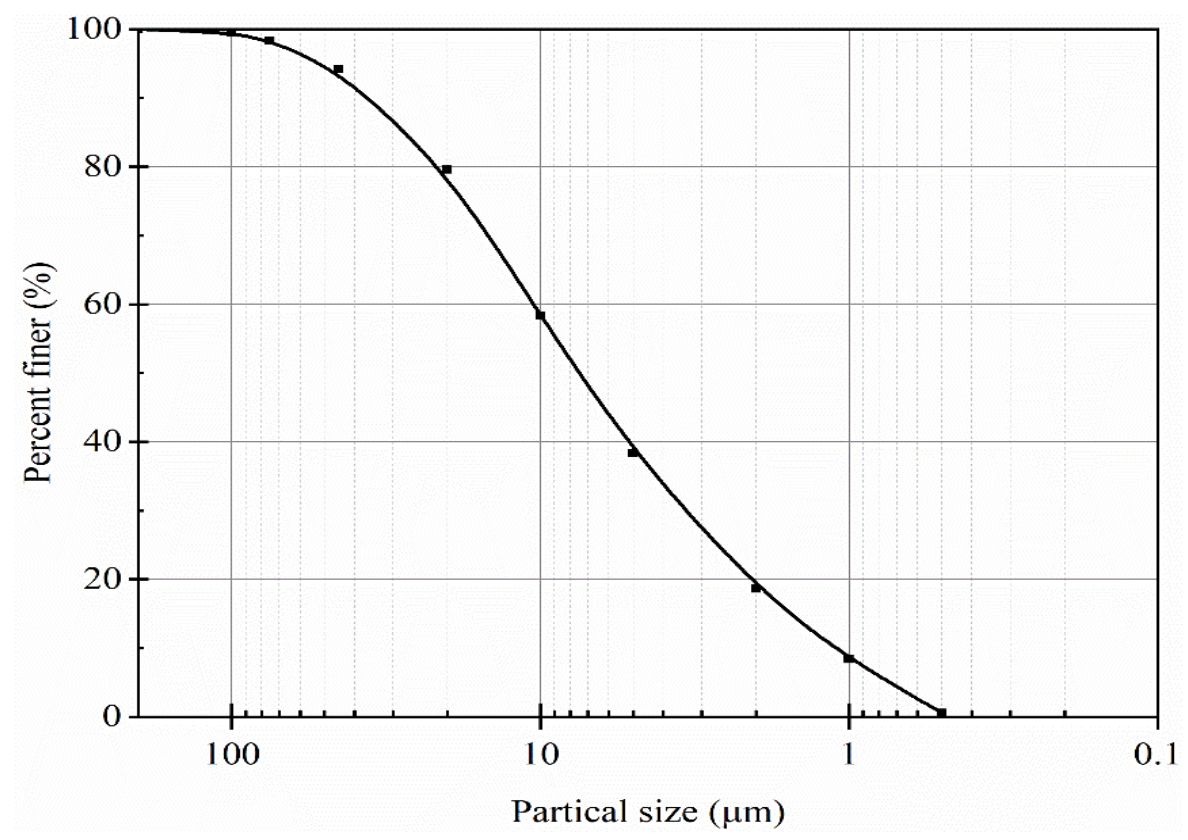

Figure 1. Particle size distribution of the sludge used in the laboratory experiments.

In this study, ground granulated blast furnace slag (GGBS) was selected because of its environmental, technical, and economic benefits $[15,23]$. As recently mentioned above, reactive magnesia is proved to be a good activator for GGBS. However, the price is costly. In China, for example, the price of magnesia varies from US\$180 to US\$350 per ton compared to lime (i.e., US $\$ 30$ to US $\$ 80$ per ton) according to Beijing HL Consulting Company 2009 [24]. In this study, using lime as an activator of GGBS in the stabilization of contaminated CMS is a way to cut down the total cost of treatment. Another reason for selecting lime is its high efficiency for heavy metal precipitation. The ordinary Portland cement 
was also used as the conventional binder in solidification/stabilization for comparison. The OPC used in this experiment was OPC.42.5 and is manufactured in China. The GGBS and $\mathrm{CaO}$ used for the experiment were obtained as a white powder from a local supplier in Wuhan. The physicochemical properties of GGBS, $\mathrm{CaO}$, and OPC were determined via $X$-ray fluorescence (XRF) test and listed in Table 2 . As previously mentioned, heavy metals such as $\mathrm{Cu}, \mathrm{Pb}$, and $\mathrm{Zn}$ were targeted. Finally, $\mathrm{Zn}\left(\mathrm{NO}_{3}\right)_{2} \cdot 6 \mathrm{H}_{2} \mathrm{O}, \mathrm{Pb}\left(\mathrm{NO}_{3}\right)_{2}$, and $\mathrm{Cu}$ $\left(\mathrm{NO}_{3}\right)_{2} \cdot 3 \mathrm{H}_{2} \mathrm{O}$ were chosen to prepare the contaminated sludge and were obtained from Wuhan Xinshenshi Chemical Technology Co., Ltd. The reason for using nitrate as the contamination source is that nitrate is inert to cement hydration [25].

Table 2. Chemical compositions of materials.

\begin{tabular}{|c|c|c|c|c|c|c|c|c|c|c|}
\hline Composition & $\begin{array}{c}\mathrm{CaO} \\
(w \mathrm{t} . \%)\end{array}$ & $\begin{array}{c}\mathrm{SiO}_{2} \\
\text { (wt. \%) }\end{array}$ & $\begin{array}{l}\mathrm{Al}_{2} \mathrm{O}_{3} \\
\text { (wt.\%) }\end{array}$ & $\begin{array}{l}\mathrm{Fe}_{2} \mathrm{O}_{3} \\
\text { (wt. } \% \text { ) }\end{array}$ & $\begin{array}{l}\mathrm{MgO} \\
\text { (wt.\%) }\end{array}$ & $\begin{array}{c}\mathrm{K}_{2} \mathrm{O} \\
\text { (wt.\%) }\end{array}$ & $\begin{array}{c}\mathrm{SO}_{3} \\
\text { (wt. \%) }\end{array}$ & $\begin{array}{l}\mathrm{Na}_{2} \mathrm{O} \\
(w \mathrm{t} . \%)\end{array}$ & $\begin{array}{l}\text { Others } \\
\text { (wt.\%) }\end{array}$ & $\begin{array}{l}\text { Loss on Ignition } \\
\text { (wt. } \%)\end{array}$ \\
\hline OPC & 59.81 & 22.33 & 6.26 & 2.54 & 3.41 & 0.70 & 4.02 & 0.68 & - & 0.25 \\
\hline $\mathrm{CaO}$ & 92.1 & 1.46 & 0.68 & 0.101 & 4.79 & 0.017 & 0.19 & - & 0.152 & - \\
\hline GGBS & 38.00 & 36.3 & 14.29 & 0.24 & 7.74 & 0.43 & 2.33 & 0.22 & - & 0.45 \\
\hline CMS & 48.38 & 21.59 & 6.56 & 15.80 & 3.39 & 0.65 & 1.20 & - & 1.79 & 0.64 \\
\hline
\end{tabular}

\subsection{Preparation of Contaminated Mining Sludge (CMS) at High Water Content}

Testing materials were obtained from real tailings with their original amount of contaminants, as shown in Table 1 would have another added value for the mining company. However, this current study investigates the effects of lime-activated GGBS and ordinary Portland cement-treated high concentrations of several heavy metals. In addition, the initial total heavy metal concentrations showed in Table 1 were below the standard value according to the background value of soil environment in China (China National Environmental Monitoring Center, Beijing, China, 1990). Furthermore, one contaminant concentrations (i.e., (i) Cu. $2901.53 \mathrm{mg} / \mathrm{kg}$, (ii) Pb. $94.38 \mathrm{mg} / \mathrm{kg}$, and (iii) Zn. $1614.73 \mathrm{mg} / \mathrm{kg}$ ), corresponding to middle pollution of $\mathrm{Pb}$ and the high concentration degree of $\mathrm{Zn}$ were selected as the target values for $\mathrm{Cu}, \mathrm{Pb}$, and $\mathrm{Zn}$, contaminated CMS in this study according to the background value of soil environment in China [26]. Four water contents varying from $100 \%$ to $160 \%$ have been considered in the experiments. Moreover, contaminated sludge specimens were prepared by dissolving the predetermined amount of $\mathrm{Zn}\left(\mathrm{NO}_{3}\right)_{2} \cdot 6 \mathrm{H}_{2} \mathrm{O}$, $\mathrm{Pb}\left(\mathrm{NO}_{3}\right)_{2}$, and $\mathrm{Cu}\left(\mathrm{NO}_{3}\right)_{2} \cdot 3 \mathrm{H}_{2} \mathrm{O}$ solution in water and mixing with the sludge. The mixing was carried out through an electric agitator for $10 \mathrm{~min}$ following the standardized mixing procedure and braised for 10 days under standard curing conditions to allow heavy metal and sludge to reach equilibrium [25]. The binder content was set at $10 \%, 12 \%, 15 \%$, and $20 \%$ by weight of dry sludge weight, respectively. In the case of lime-activated GGBS, the quicklime (the activator) to GGBS ratio is 1:3, as recommended by $[5,12]$. Furthermore, the binders were added to the contaminated sludge on predetermined dry sludge weight and mixed thoroughly for $10 \mathrm{~min}$ with an electronic mixer to obtain a homogenous mixture. The mix was then poured in cylindrical molds $(50 \mathrm{~mm}$ in diameter and $100 \mathrm{~mm}$ high) and were cured in the curing box at temperatures $25 \pm 1{ }^{\circ} \mathrm{C}$ and humidity was maintained at $95 \pm 3 \%$.

\subsection{Testing Procedure}

A total of 16 cases were conducted during the laboratory experiment, and the designed proportions are summarized in Table 3 . The 16 cases were divided into four groups (i.e., A-D). Group A includes four CMS cases stabilized with different values of OPC content. Group B includes four CMS cases stabilized with OPC at different values of water content. Furthermore, Group C and D include four CMS cases stabilized with lime-activated GGBS at different binder content and different water content. 
Table 3. Testing program.

\begin{tabular}{|c|c|c|c|c|c|c|c|c|}
\hline Mix Type & Binder Type & Group & Case No. & $W(\%)$ & $A_{\mathrm{w}}(\%)$ & Curing Time & $\begin{array}{c}\text { No. of } \\
\text { Specimens } \\
\text { Prepared }\end{array}$ & Testing Items \\
\hline \multirow{8}{*}{ OPC } & \multirow{8}{*}{$\begin{array}{l}\text { Ordinary } \\
\text { Portland } \\
\text { cement }\end{array}$} & \multirow{4}{*}{ A } & A1 & 120 & 10 & \multirow{16}{*}{$\begin{array}{l}7,14,21 \text { and } \\
28 \text { days }\end{array}$} & 8 & \multirow{16}{*}{$\begin{array}{l}\text { UCS at 7,14, } 21 \text { and } \\
28 \text {-day for } \\
\text { all specimens } \\
\text { TCLP at } 7,14,21 \text {, and } \\
28 \text {-day for } \\
\text { all specimens } \\
\text { XRD at } 28 \text {-day for } \\
\text { selected specimens } \\
\text { SEM at } 28 \text {-day for } \\
\text { selected specimens }\end{array}$} \\
\hline & & & A2 & 120 & 12 & & 8 & \\
\hline & & & A3 & 120 & 15 & & 8 & \\
\hline & & & A4 & 120 & 20 & & 8 & \\
\hline & & \multirow{4}{*}{ B } & B1 & 100 & 12 & & 8 & \\
\hline & & & B2 & 120 & 12 & & 8 & \\
\hline & & & B3 & 140 & 12 & & 8 & \\
\hline & & & B4 & 160 & 12 & & 8 & \\
\hline \multirow{8}{*}{ CG } & & \multirow{5}{*}{ C } & $\mathrm{C} 1$ & 120 & 10 & & 8 & \\
\hline & & & $\mathrm{C} 2$ & 120 & 12 & & 8 & \\
\hline & & & $\mathrm{C} 3$ & 120 & 15 & & 8 & \\
\hline & CaO-GGBS & & C4 & 120 & 20 & & 8 & \\
\hline & $(1: 3)$ & & D1 & 100 & 12 & & 8 & \\
\hline & & \multirow{3}{*}{ D } & D2 & 120 & 12 & & 8 & \\
\hline & & & D3 & 140 & 12 & & 8 & \\
\hline & & & D4 & 160 & 12 & & 8 & \\
\hline
\end{tabular}

Four curing times were considered for each testing case $(7,14,21$, and 28 days). In fact, the strength of a soil-cement composite improves with curing age. However, preliminary research was conducted in this study to compare the efficacy of S/S for the treatment of mining sludge with high water content utilizing quick lime $(\mathrm{CaO})$ activated ground granulated blast furnace slag (GGBS) to ordinary Portland cement (OPC). After 7, 14, 21 , and 28 days, specimens were extruded from the molds, and unconfined compression strength tests (UCS) were conducted to determine their crushing strength according to the ASTM standard D-1633. Following UCS, the samples were crushed to reduce the particle size to less than $2 \mathrm{~mm}$ in order to determine the specimen's leachability using the toxicity characteristics leaching procedure experiment (TCLP) defined by EPA method 1311. For XRD analysis, the samples obtained from UCS were crushed and sieved through a $0.075 \mathrm{~mm}$ sieve to get a fine powder, and the samples were scanned in ranges from 10 to $70(2 \varnothing)$ using a Rigku D/Max-2500 X-ray diffractometer with a Cu-K $\alpha$ source to identify the crystalline phases. Scanning electron microscopy (SEM) was also used on the selected samples to analyze the microstructure properties of the stabilized soils.

\section{Results and Discussion}

\subsection{Strength Characteristics of Treated Mining Sludge at High Water Content}

Figure 2 illustrates the UCS results of CMS at high water content stabilized by CG and OPC at different binder content and curing time (groups A and C). The CG stabilized CMS samples were not strong enough to be de-molded after 7-day of curing time. The CG stabilized CMS showed a lower 7-day UCS than OPC stabilized CMG, but the formers produced higher UCS values at later curing ages. This is attributed to the slow hydration rate of GGBS at an early age, which has nevertheless resulted in higher longterm strength once activated, as reported in previous studies [27,28]. The 28 days UCS of the stabilized CMS specimens increases with binder content and curing time as expected due to the formation of cementitious phase. When the CG content increased from 10 to $20 \%$, the compressive strength increased to $118.18 \mathrm{kPa}$ and $1003.86 \mathrm{kPa}$ at 28-day curing time, respectively. 


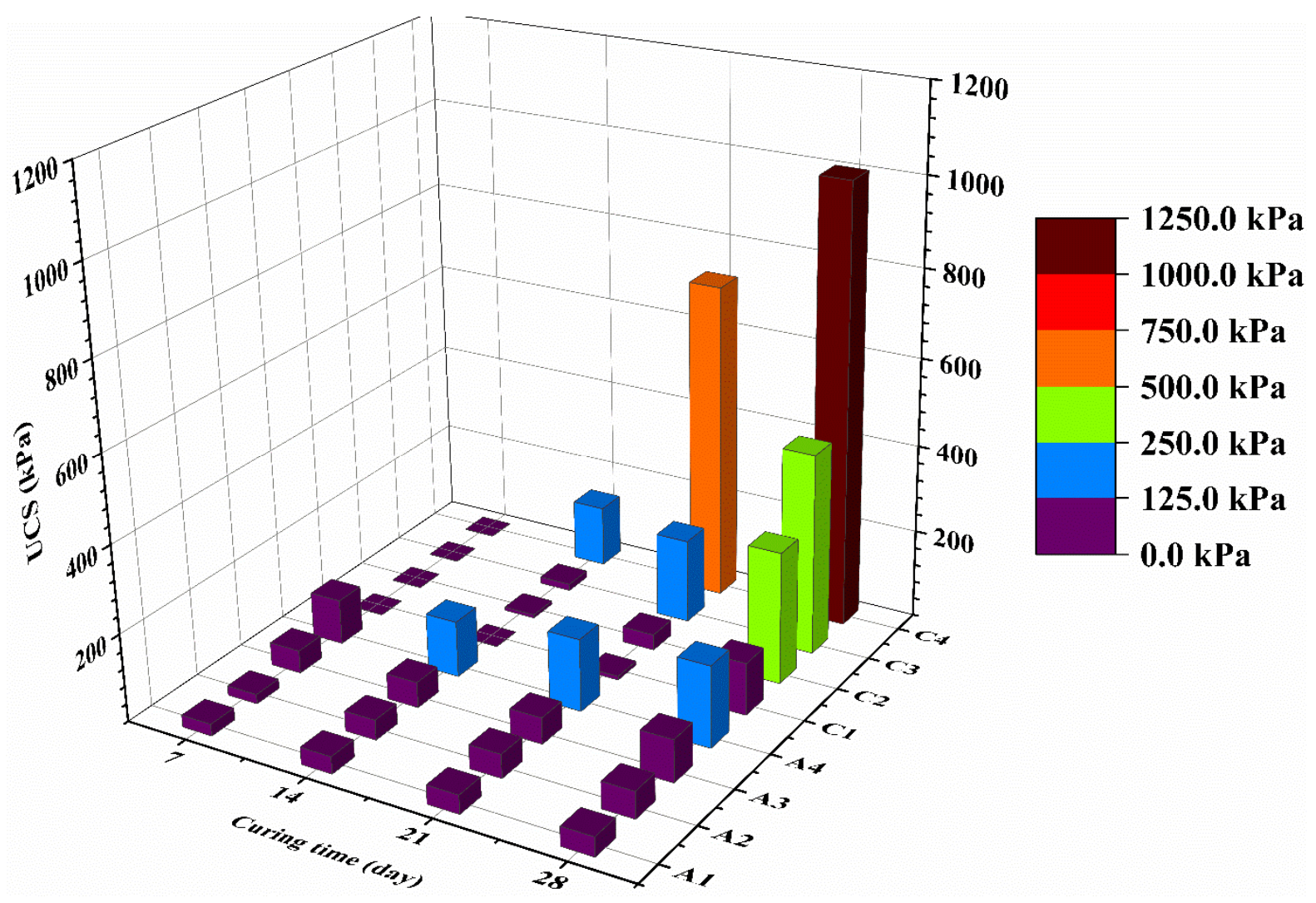

Figure 2. UCS of solidified samples with the same water content.

Furthermore, the UCS values of CG stabilized CMS increased significantly with curing time compared to OPC stabilized CMS. After 28-day of curing time, CG stabilized CMS showed 5.44 times higher UCS than OPC stabilized CMS at the same water content and binder content. This could be explained by the higher hydration rate of GGBS activated by lime and the increase of hydrates, such as CSH and CASH, hydrotalcite-like phases in stabilized CMS, which can increase the UCS of samples. None of the OPC stabilized CMS fulfilled the US EPA criterion (0.35 MPa) even after the 28-day curing time due to their lower strength, whereas the CG stabilized CMS met these criteria after the 21-day curing time.

Figure 3 showed the 28-day UCS results of stabilized CMS at different water content values (cases B and D). It can be observed that, at 28-day, the UCS decreases with the increase of water content for both stabilized specimens. Indeed, the UCS decreases approximately by 3.9 times for CG stabilized specimens and 1.7 times for OPC samples when increasing the water content from 100 to $160 \%$ after 28-day of curing. The strength of a stabilized soil also depends on the water content of the soil-cement mixture, as it is for the concrete mixture. It is known that UCS depends on the quality of the pore structure of cement stabilized matrix. Additionally, this quality is influenced by the type and quantity of constituents that contribute to the pore structure, namely OPC hydration products. However, for all the stabilized CMS, the CG produces a higher UCS up to eight orders of magnitude than OPC stabilized samples. These results were attributed to the formation of a more voluminous hydration product such as hydrotalcite $(\mathrm{Ht})$ in the CG stabilized CMS [29]. Ht is more voluminous than C S H, which effectively fills soil pores and leads to higher strength developments [18,30]. Additionally, stabilized high water content CMS can be used as structural backfill material because the minimum strength required is $100 \mathrm{KPa}$, as reported by [31]. 


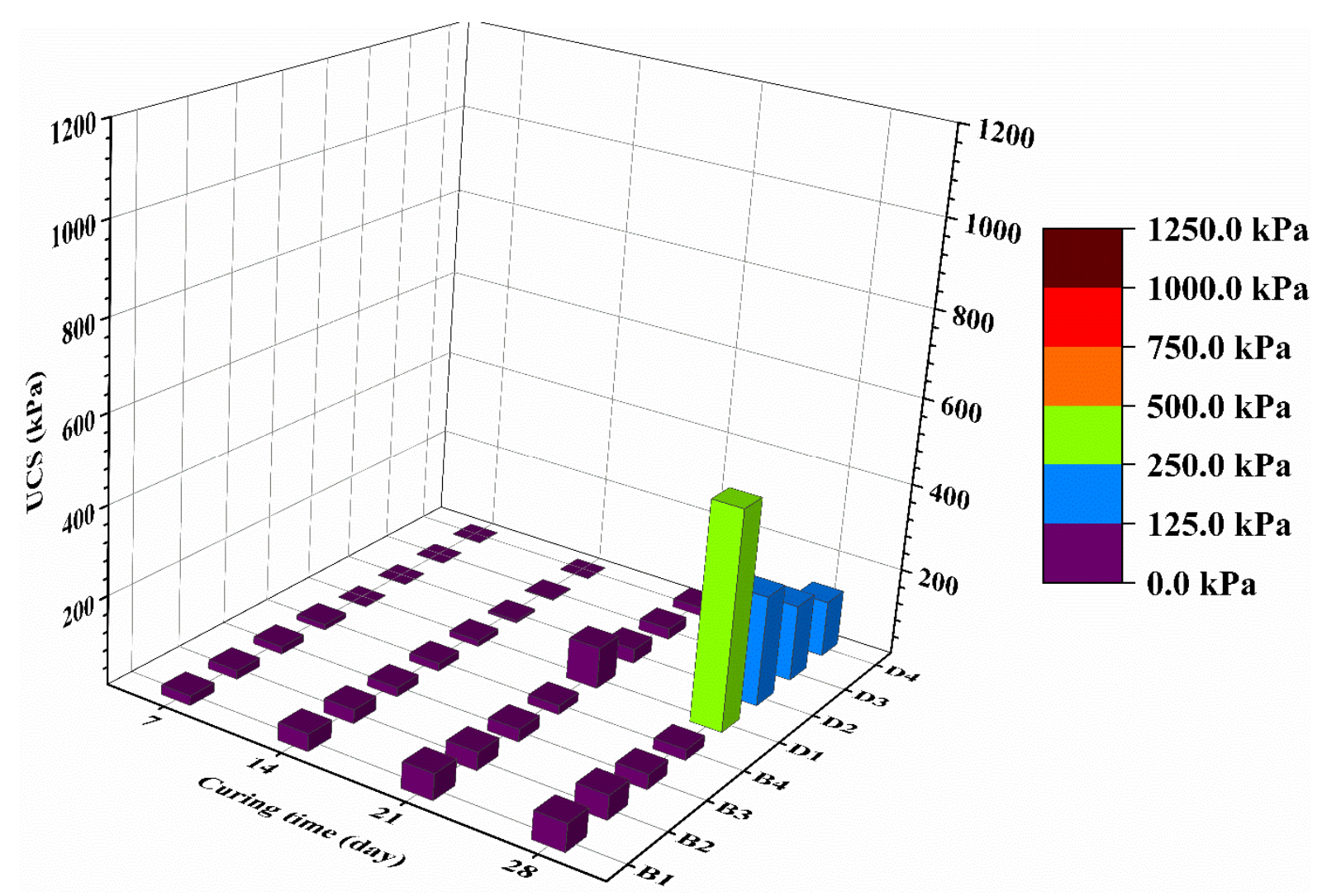

Figure 3. UCS of solidified samples at the same binder content and different water content.

\subsection{Heavy Metal Leaching Behavior of Treated Mining Sludge at High Water Content}

The TCLP experiments were also carried out on stabilized CMS samples, which could represent the long-term stability of S/S material in the context of leaching. Figure 4 shows the detailed results of heavy metal leachability of $\mathrm{Cu}, \mathrm{Pb}$, and $\mathrm{Zn}$ stabilized by $\mathrm{CG}$ and OPC at the same water content and different binder content. It can be seen that leaching concentration of heavy metals such as $\mathrm{Cu}, \mathrm{Pb}$, and $\mathrm{Zn}$ from stabilized CMS were lower than $100 \mathrm{mg} / \mathrm{L}, 5 \mathrm{mg} / \mathrm{L}$, and $100 \mathrm{mg} / \mathrm{L}$, respectively, which are the regulatory limit specified by Chinese standard method. The leachability of heavy metals decreases with the curing time and the increase of binder content for both CG and OPC stabilized CMS. This shows that by incorporating binders, the leachability of heavy metals in CMS decreases, which is primarily due to their insoluble hydroxides and/or complexes, as seen in the XRD result (Figure 6).

The leached $\mathrm{Cu}$ and $\mathrm{Pb}$ concentrations from OPC stabilized CMS were on the lower side than CG stabilized CMS. More specifically, OPC stabilized CMS exhibited 6.95\% and $38.8 \%$ lower leached concentration of $\mathrm{Cu}$ and $\mathrm{Pb}$ than $\mathrm{CG}$ cases, respectively. The improved immobilization capability of OPC is attributed to encapsulation within the OPC structure, as well as the chemical reaction between $\mathrm{Ca}(\mathrm{OH})_{2}$ and heavy metals [32]. This is consistent with the findings of [33], who revealed that OPC-treated contaminated soil had lower $\mathrm{Pb}$ and $\mathrm{Cu}$ leachability than $\mathrm{CaO}$-treated contaminated soil. In contrast, CG stabilized CMS showed $15.7 \%$ lower leachability of $\mathrm{Zn}$ than OPC stabilized CMS.

This pronounced decrease in $\mathrm{Zn}$ leachability in CG cases is due to the production of more voluminous hydration products such as CSH and hydrotalcite, resulting in a dense stabilized matrix that provides greater resistance to TCLP acid solution [34]. Besides, hydrotalcite formed in CG cases (see XRD results) is an effective heavy metal absorber and reduces $\mathrm{Zn}$ 's leachability through isomorphic substitution $[18,35]$. 

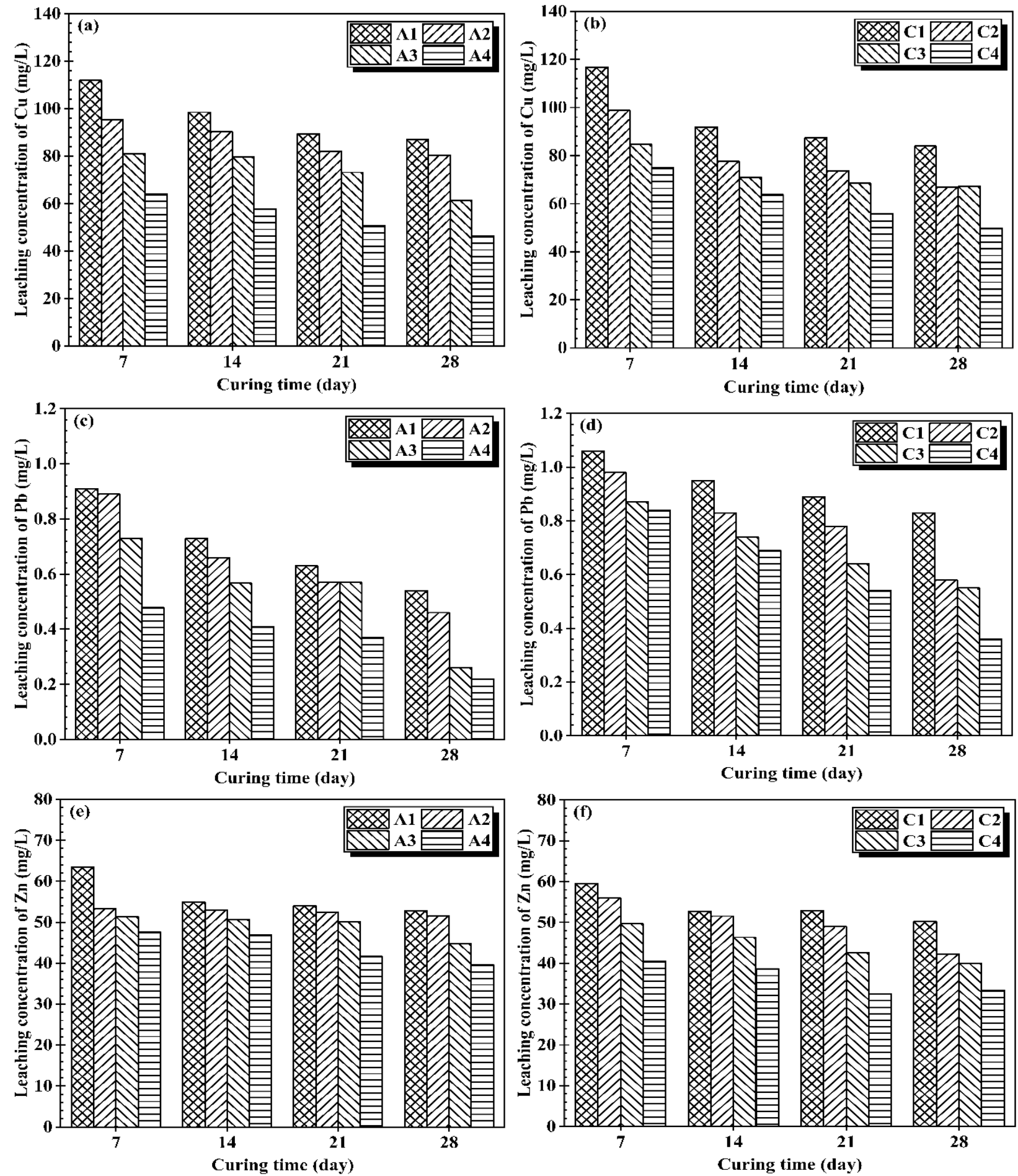

Figure 4. Leaching concentration vs. binder percentage: (a) $\mathrm{Cu}$ in OPC samples, (b) $\mathrm{Cu}$ in CG samples, (c) $\mathrm{Pb}$ in OPC samples, (d) Pb in CG samples, (e) Zn in OPC samples, (f) Zn in CG samples. 
The increase in water content (Figure 5) led to the rise in the leachability of heavy metals in both cases. The leachability increases significantly when increasing the water content from $100 \%$ to $160 \%$. For all cases, OPC stabilized CMS leach out a higher concentration of $\mathrm{Zn}$ than CG stabilized CMS except for $\mathrm{Pb}$ and $\mathrm{Cu}$. Analysis of Figures 3 and 5 showed that the treated CMS with a high water content present a lower UCS and higher leachability compared to those treated with lower water content. Furthermore, the CMS stabilized by CG showed better performance than OPC treated specimens, which could be responsible for better encapsulation of heavy metal [30]. Although the increase of water content has a significant effect on OPC stabilized CMS, the heavy metal concentrations in the leachate were below the regulatory limit according to the Chinese standard after 28 days of curing. The increase in water content did not significantly affect the immobilization of $\mathrm{Pb}$ because the initial concentration of $\mathrm{Pb}$ on the CMS is not that higher. Therefore, CG-based solidification/stabilization can be used for the safe disposal of high water CMS treated at $12 \%$ binder content. The replacement of OPC with lime-activated GGBS lead to an improvement in the heavy metal retention compared to OPC stabilized CMS. The above findings demonstrated that the proposed CG binder was effective in the S/S of heavy metal contaminated sludge at high water content.

\subsection{XRD Analysis of Treated Mining Sludge at High Water Content}

The 28-day crystalline phases of OPC and CG cases determined by XRD analysis are shown in Figure 6 Quartz has been found as the common compound of CMS, reflecting the nature of used mining sludge. Typical hydration products such as Calcium silicate hydrate $(\mathrm{CSH})$, calcium aluminate silicate hydrate $(\mathrm{CASH})$, and ettringite were also identified in both OPC and CG cases, suggesting that the major hydration products of CG stabilized CMS were similar to that of OPC stabilized CMS. This is in agreement with previous findings $[16,36]$. However, the additional peaks of hydrotalcite were also detected in CG cases, which is the only difference between the hydration products of CG and OPC stabilized CMS. Hydrotalcite formation in the CG system is expected as a result of magnesium dissolution and precipitation from the GGBS particles. The development of these voluminous hydration products could increase the binding capability, resulting in higher strength development of stabilized CMS [12]. Calcite was also detected, which is the result of the reaction between $\mathrm{CaO}$ and gas-phase $\mathrm{CO}_{2}$.

Under high alkaline conditions, $\mathrm{Pb}$ was solidified/stabilized on the surface of $\mathrm{CSH}$ by an adsorption mechanism and chemical reactions to form insoluble lead silicate, as shown in Figure 6 Trace peaks of Zinc oxide and copper oxide were identified in both specimens (Figure 6), indicating that $\mathrm{Cu}$ and $\mathrm{Zn}$ were mainly precipitated as oxide. Zinc silicate has also been identified in XRD patterns of both cases, which is parallel with the findings of [37], who reported that $\mathrm{Zn}$ is usually bound to carbonate and Fe/Mn oxide phases. The $\mathrm{Zn}$ tetrahedral can also be bound to the CSH tetrahedral silicate chains, leading to $\mathrm{Zn}$ retention. $\mathrm{Zn}$ was then stabilized/solidified by CSH adsorption, precipitation, and incorporation into the components of hydration products such as $\mathrm{CSH}$ and hydrotalcite. Another complex called calcium zincate $\left(\mathrm{CaZn}_{2}(\mathrm{OH}) 6 \cdot 2 \mathrm{H}_{2} \mathrm{O}\right)$ was also observed in both cases, which is supposed to form from the $\mathrm{Ca}(\mathrm{OH})_{2}$ and $\mathrm{Zn}(\mathrm{OH})_{2}$ reaction. In addition, due to $\mathrm{Zn}$ 's retardant effect on cement hydration, portlandite $\left(\mathrm{Ca}(\mathrm{OH})_{2},\right)$ one of the major hydration products, was not detected in the OPC stabilized CMS, which is consistent with a finding previously reported in the literature [25]. No portlandite was also detected in the CG cases. The absence of portlandite in the CG stabilized samples is due to its consumption during the GGBS activation, which agrees with [38]. 

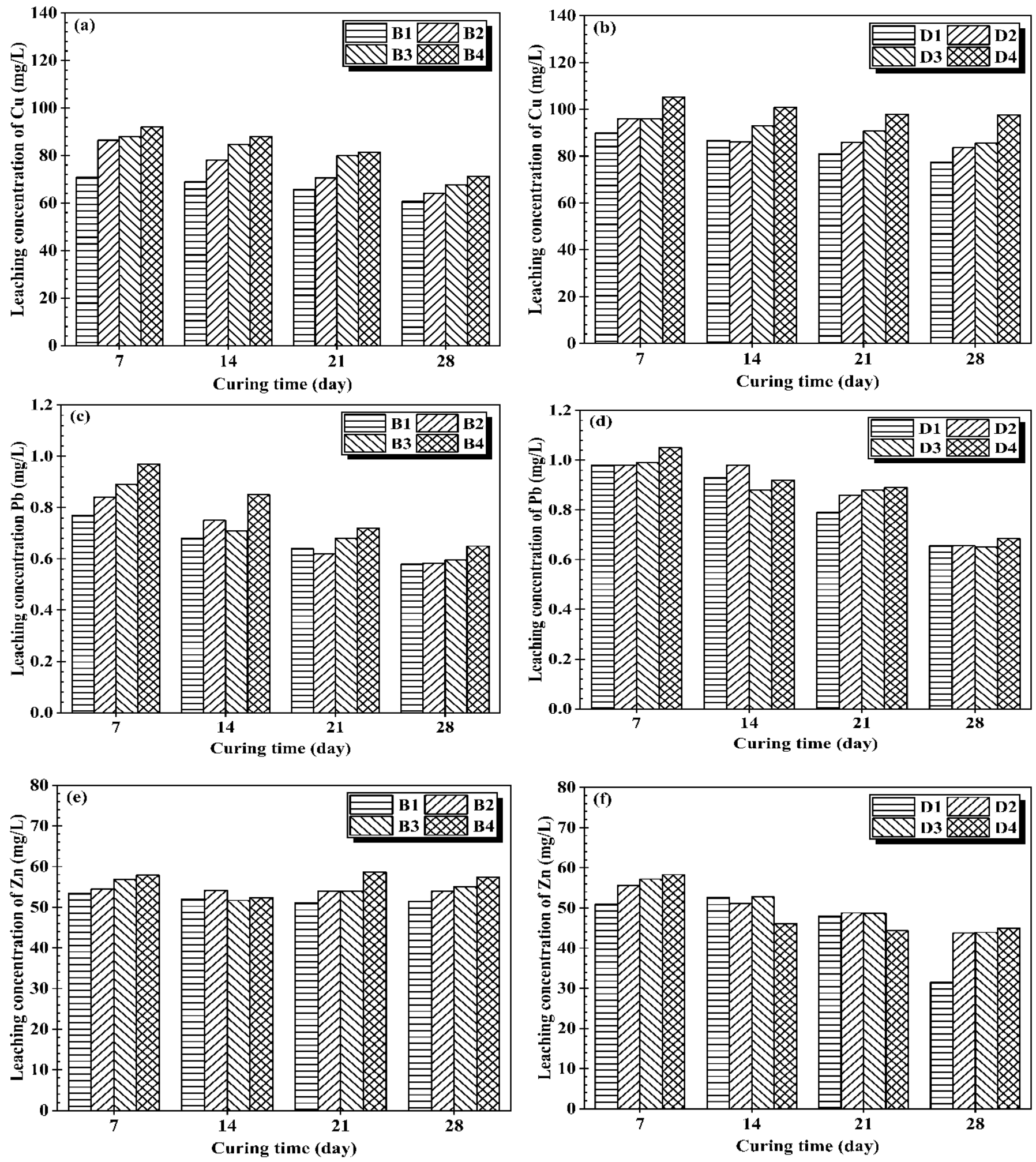

Figure 5. Leaching concentration vs. water content: (a) leachate concentration of $\mathrm{Cu}$ in OPC samples, (b) leachate concentration of $\mathrm{Cu}$ in CG samples, (c) leachate concentration of Pb in OPC samples, (d) leachate concentration of Pb in CG samples, (e) leachate concentration of $\mathrm{Zn}$ in OPC samples, (f) leachate concentration of $\mathrm{Zn}$ in CG samples. 


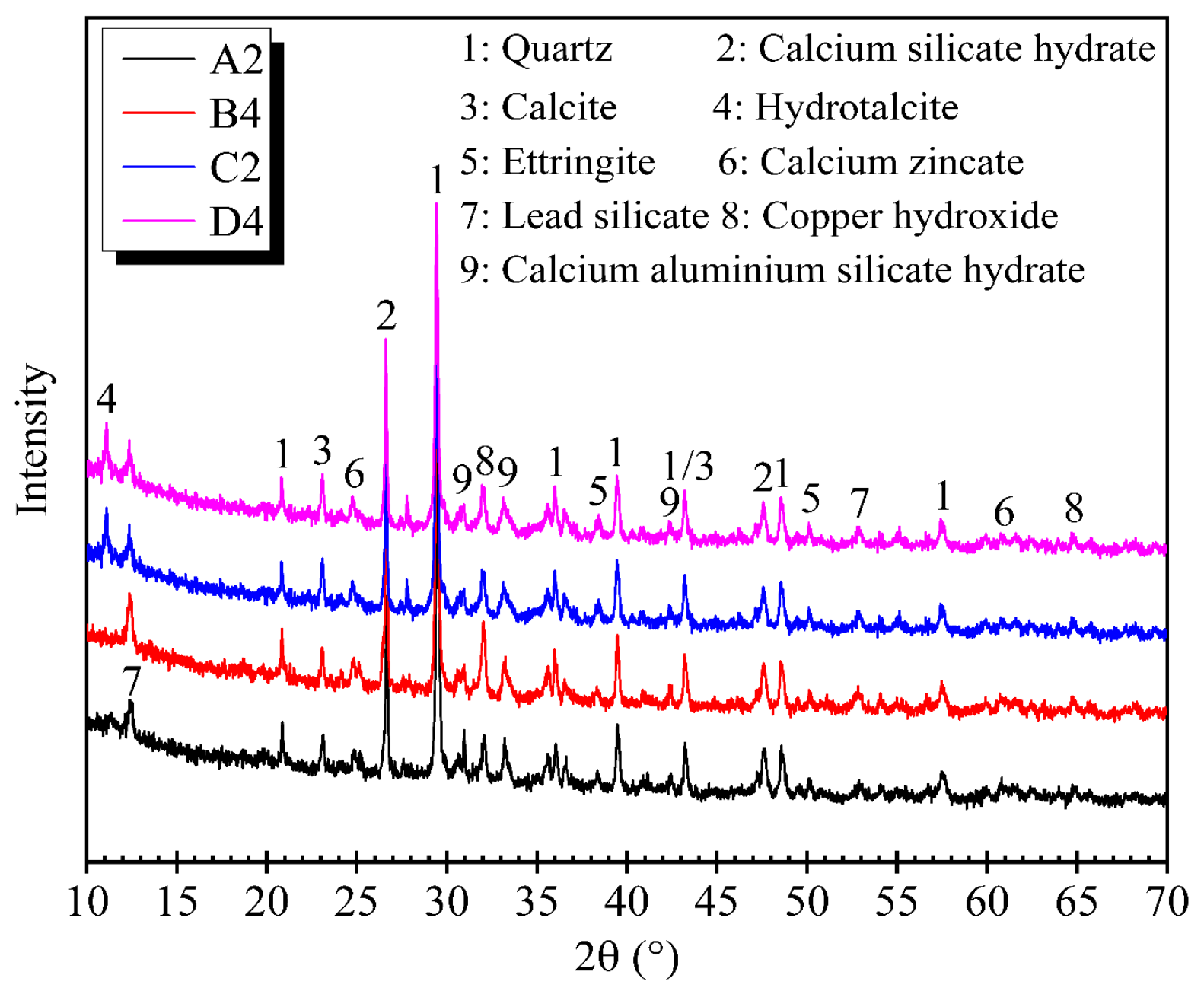

Figure 6. XRD diffractograms of CMS samples treated by OPC and CG after 28 days of curing.

\subsection{SEM Images for Treated Mining Sludge at High Water Content}

SEM tests were performed to examine the microstructure development on the typical 28-day OPC and CG stabilized CMS specimens, and the results are shown in Figure 7. The OPC stabilized CMS microstructure with $12 \%$ OPC at $120 \%$ water content is shown in Figure 7a, and the CG stabilized CMS with $12 \%$ CG at $120 \%$ water content is shown in Figure $7 \mathrm{~b}$. The analysis of the micrograph indicates that the soil particles were disorderly distributed with a large number of small pores. The CG and OPC hydration products of gel-like CSH, platy CASH gels, platelet hydrotalcite, and needle-like ettringite crystal have been filled into the pores of these CMS particles, leading to the disappearance of large-scale pores. This is consistent with [39], who reported that CASH appeared to be platy in soil-lime/cement reaction. Such cementation and filling ability of hydration products contributed to the strength development of stabilized CMS. The analysis of Figure 7c,d showed a large amount of pore, indicating that the increase of water content from $120 \%$ to $160 \%$ for OPC and CG treated specimens significantly affected the microstructure.

When increasing the water content, the hydrates products in both cases remain the same such as $\mathrm{CSH}, \mathrm{CASH}$, hydroltalcite, and ettringite. However, a large quantity of pores has been detected (Figure 7c,d). Indeed, the microstructure of the stabilized CMS particles changed from a dense structure to a dispersed nature with a large number of pores due to the presence of a large amount of water. The authors of [40] previously reported similar observations due to an increase in water content. Figure $7 \mathrm{~b}, \mathrm{~d}$ depict the microstructure of CG stabilized CMS samples with a $12 \%$ binder content produced, and the CMS particles have been strongly cemented, resulting in significant improvement in the development of 
strength. This agrees with the UCS results presented in Figures 3 and 4 showing that the 28 days UCS of CMS stabilized with CG were higher than OPC under the same water content.
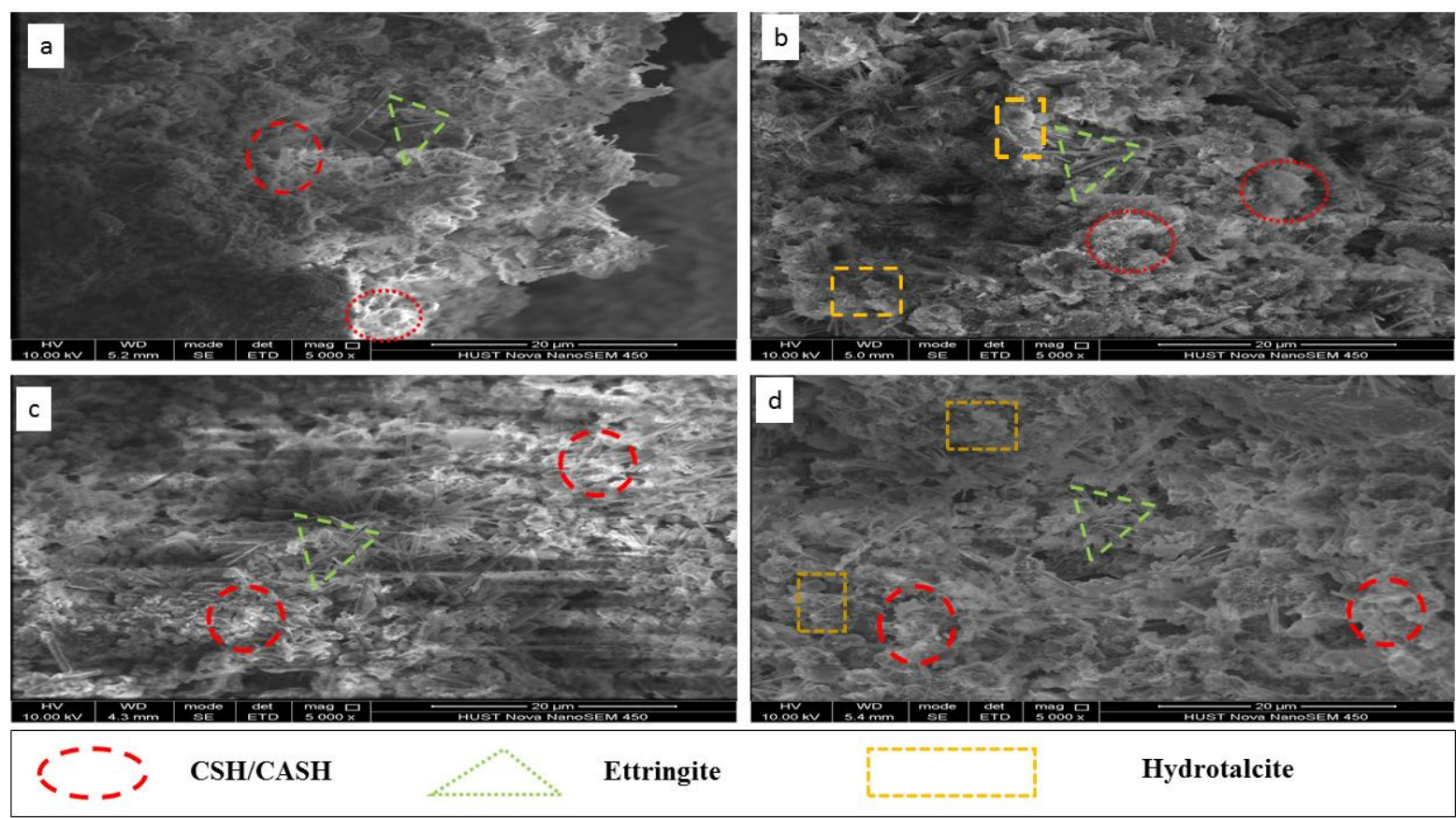

Hydrotalcite

Figure 7. Microstructure of contaminated sludge treated by OPC and CG after 28 days of curing: (a) case A2, (b) case C2, (c) case B4, (d) case D4.

\section{Conclusions}

In this study, lime-activated GGBS based solidification/stabilization has been proposed for the treatment of high water CMS. A series of tests were conducted to evaluate the effect of water content and binder content on the strength characteristics and leaching behavior of the treated material. The main conclusions drawn from the analysis include:

1. Lime-activated GGBS has substantially better performance than OPC in the aspect of strength development of treated mining sludge. At 28-day, the UCS of CG stabilized CMS showed 5.44 times higher UCS than OPC stabilized CMS at the same water content and binder content.

2. Both CG and OPC samples exhibit a decrease in the leaching concentration of heavy metal with an increase in curing time. However, CG stabilized samples show comparable capability of heavy metal stabilization in contrast to OPC.

3. XRD patterns showed that the main hydration products of both CG and OPC mixes were $\mathrm{CSH}, \mathrm{CASH}$, and ettringite. The hydrotalcite produced in the CG mix was the only difference between the hydration products of CG and OPC mixes.

4. SEM micrographs exhibited that CG mix developed dense microstructure due to the formation of more voluminous hydration products such as hydrotalcite, filling the pores between CMS particles more effectively, resulting in a dense stabilized matrix.

Author Contributions: T.A.F.: Conceptualization, Investigation, Methodology, Experiments, Formal analysis, Data Analysis, Writing-Original Draft, Writing-Review and Editing. R.Z.: Investigation, Methodology Original Draft-Writing-Review and Editing. X.H.: Experiments-Data AnalysisReview and Editing. Y.M.: Investigation, Methodology Original Draft-Writing-Review and Editing. J.Z.: Investigation, Methodology Original Draft-Writing-Review and Editing. A.K.M.: Data Analysis, Writing-Review and Editing. All authors have read and agreed to the published version of the manuscript. 
Funding: This study has been supported by the National Key Research and Development Program of China (No.2016YFC0800200) and the National Natural Science Foundation of China (NSFC) (No. 51978303; No. 51678266). Their financial support is gratefully acknowledged.

Institutional Review Board Statement: Not applicable.

Informed Consent Statement: Not applicable.

Data Availability Statement: Data is contained within the article.

Acknowledgments: The authors would like to acknowledge and appreciate the support received from the Institute of Geotechnical and Underground Engineering, Huazhong University of Science and Technology, Wuhan, China.

Conflicts of Interest: The authors declare no conflict of interest.

\section{Nomenclature}

$\begin{array}{ll}\text { CMS } & \text { contaminated mining sludge } \\ \text { S/S } & \text { solidification/stabilization } \\ \text { U.C.S. } & \text { unconfined compressive strength } \\ \text { TCLP } & \text { toxicity characteristics leaching procedure } \\ \text { ASTM } & \text { American standard of testing material } \\ \text { EPA } & \text { environment protection agency } \\ W & \text { water content } \\ A_{\mathrm{w}} & \text { binder content } \\ \text { OPC } & \text { ordinary Portland cement } \\ \text { CG } & \text { lime activated GGBS } \\ \text { XRD } & \text { X-ray diffraction } \\ \text { XRF } & \text { X-ray fluorescence } \\ \text { SEM } & \text { scanning electron microscopy } \\ \text { Ht } & \text { hydrotalcite }\end{array}$

\section{References}

1. Young, G.; Chen, Y.; Yang, M. Concentrations, distribution, and risk assessment of heavy metals in the iron tailings of Yeshan National Mine Park in Nanjing, China. Chemosphere 2021, 271, 129546. [CrossRef] [PubMed]

2. Glotov, V.E.; Chlachula, J.; Glotova, L.P.; Little, E. Causes and environmental impact of the gold-tailings dam failure at Karamken, the Russian Far East. Eng. Geol. 2018, 245, 236-247. [CrossRef]

3. Xia, W.-Y.; Du, Y.-J.; Li, F.-S.; Guo, G.-L.; Yan, X.-L.; Li, C.-P.; Arulrajah, A.; Wang, F.; Wang, S. Field evaluation of a new hydroxyapatite based binder for ex-situ solidification/stabilization of a heavy metal contaminated site soil around a $\mathrm{Pb}-\mathrm{Zn}$ smelter. Constr. Build. Mater. 2019, 210, 278-288. [CrossRef]

4. Peng, W.; Chaosheng, T.; Kaiqiang, S.; Zhiguo, C.; Shikang, X.; Bin, S. Advances on solidification/stabilization of sludge disposal. Gongcheng Dizhixue Bao J. Eng. Geol. 2016, 24, 649-660.

5. Yi, Y.; Liska, M.; Jin, F.; Al-Tabbaa, A. Mechanism of reactive magnesia-Ground granulated blastfurnace slag (GGBS) soil stabilization. Can. Geotech. J. 2016, 53, 773-782. [CrossRef]

6. Liu, Y.; Tang, Y.; Zhong, G.; Zeng, H. A comparison study on heavy metal/metalloid stabilization in Maozhou River sediment by five types of amendments. J. Soils Sediments 2019, 19, 3922-3933. [CrossRef]

7. Kogbara, R.B.; Yi, Y.; Al-Tabbaa, A. Process envelopes for stabilisation/solidification of contaminated soil using lime-slag blend. Environ. Sci. Pollut. Res. 2011, 18, 1286-1296. [CrossRef]

8. Feng, Y.-S.; Du, Y.-J.; Xia, W.-Y.; Reddy, K.R. Pilot-scale field investigation of ex situ solidification/stabilization of soils with inorganic contaminants using two novel binders. Acta Geotech. 2019, 15, 1467-1480. [CrossRef]

9. Wang, L.; Chen, L.; Tsang, D.C.W.; Zhou, Y.; Rinklebe, J.; Song, H.; Kwon, E.E.; Baek, K.; Ok, Y.S. Mechanistic insights into red mud, blast furnace slag, or metakaolin-assisted stabilization/solidification of arsenic-contaminated sediment. Environ. Int. 2019, 133, 105247. [CrossRef]

10. Keramatikerman, M.; Chegenizadeh, A.; Nikraz, H. Effect of GGBFS and lime binders on the engineering properties of clay. Appl. Clay Sci. 2016, 132-133, 722-730. [CrossRef]

11. Zhang, W.-L.; Zhao, L.-Y.; McCabe, B.A.; Chen, Y.-H.; Morrison, L. Science of the Total Environment Dredged marine sediments stabilized/solidified with cement and GGBS: Factors affecting mechanical behaviour and leachability. Sci. Total Environ. 2020, 733, 138551. [CrossRef]

12. Goodarzi, A.R.; Movahedrad, M. Stabilization/solidification of zinc-contaminated kaolin clay using ground granulated blastfurnace slag and different types of activators. Appl. Geochem. 2017, 81, 155-165. [CrossRef] 
13. Yi, Y.; Zheng, X.; Liu, S.; Al-Tabbaa, A. Comparison of reactive magnesia- and carbide slag-activated ground granulated blastfurnace slag and Portland cement for stabilisation of a natural soil. Appl. Clay Sci. 2015, 111, 21-26. [CrossRef]

14. Jin, F.; Al-Tabbaa, A. Evaluation of novel reactive $\mathrm{MgO}$ activated slag binder for the immobilisation of lead and zinc. Chemosphere 2014, 117, 285-294. [CrossRef]

15. Lang, L.; Chen, B.; Li, N. Utilization of lime/carbide slag-activated ground granulated blast-furnace slag for dredged sludge stabilization. Mar. Georesour. Geotechnol. 2020, 39, 659-669. [CrossRef]

16. Gu, K.; Jin, F.; Al-Tabbaa, A.; Shi, B.; Liu, C.; Gao, L. Incorporation of reactive magnesia and quicklime in sustainable binders for soil stabilisation. Eng. Geol. 2015, 195, 53-62. [CrossRef]

17. Kim, M.S.; Jun, Y.; Lee, C.; Oh, J.E. Cement and Concrete Research Use of $\mathrm{CaO}$ as an activator for producing a price-competitive non-cement structural binder using ground granulated blast furnace slag. Cem. Concr. Res. 2013, 54, 208-214. [CrossRef]

18. Wang, F.; Wang, H.; Jin, F.; Al-Tabbaa, A. The performance of blended conventional and novel binders in the in-situ stabilisation/solidification of a contaminated site soil. J. Hazard. Mater. 2015, 285, 46-52. [CrossRef]

19. Kogbara, R.B.; Al-Tabbaa, A. Mechanical and leaching behaviour of slag-cement and lime-activated slag stabilised/solidified contaminated soil. Sci. Total Environ. 2011, 409, 2325-2335. [CrossRef]

20. Wuana, R.A.; Okieimen, F.E. Heavy Metals in Contaminated Soils: A Review of Sources, Chemistry, Risks and Best Available Strategies for Remediation. ISRN Ecol. 2011, 2011, 1-20. [CrossRef]

21. United States Environmental Protection Agency (USEPA). Report: Recent Developments for In Situ Treatment of Metals Contaminated Soils; United States Environmental Protection Agency, Office of Solid Waste and Emergency Response: Washington, DC, USA, 1996.

22. Luo, Y. Environmental problems in the mining of metal minerals. IOP Conf. Ser. Earth Environ. Sci. 2019, 384, 012195. [CrossRef]

23. Yi, Y.; Gu, L.; Liu, S.; Puppala, A.J. Carbide slag-activated ground granulated blastfurnace slag for soft clay stabilization. Can. Geotech. J. 2015, 52, 656-663. [CrossRef]

24. Beijing HL Consulting Company. Market Research Report on Magnesia (MgO) Industry in China; Beijing HL Consulting Company: Beijing, China, 2009.

25. Du, Y.-J.; Jiang, N.-J.; Liu, S.-Y.; Jin, F.; Singh, D.; Puppala, A.J. Engineering properties and microstructural characteristics of cement-stabilized zinc-contaminated kaolin. Can. Geotech. J. 2014, 51, 289-302. [CrossRef]

26. China National Environmental Monitoring Center (CNEMC). The Soil Background Value in China; CNEMC: Beijing, China, 1990.

27. Yi, Y.; Liska, M.; Al-Tabbaa, A. Properties of Two Model Soils Stabilized with Different Blends and Contents of GGBS, MgO, Lime, and PC. J. Mater. Civ. Eng. 2014, 26, 267-274. [CrossRef]

28. Yi, Y.; Gu, L.; Liu, S. Microstructural and mechanical properties of marine soft clay stabilized by lime-activated ground granulated blastfurnace slag. Appl. Clay Sci. 2015, 103, 71-76. [CrossRef]

29. Mastoi, A.K.; Pu, H.; Chen, X.; Nyanzi, A.S.; Jhatial, A.A. Physico-mechanical and microstructural behaviour of high-water content zinc-contaminated dredged sediment treated with integrated approach PHDVPSS. Environ. Sci. Pollut. Res. 2021, 28, 58331-58341. [CrossRef]

30. Li, Y.-C.; Min, X.-B.; Chai, L.-Y.; Shi, M.-Q.; Tang, C.-J.; Wang, Q.-W.; Liang, Y.-J.; Lei, J.; Liyang, W.-J. Co-treatment of gypsum sludge and $\mathrm{Pb} / \mathrm{Zn}$ smelting slag for the solidification of sludge containing arsenic and heavy metals. J. Environ. Manag. 2016, 181, 756-761. [CrossRef]

31. Makusa, G.P.; Mattson, H.; Knutsson, S. Shear strength evaluation of preloaded stabilized dredged sediments using CTP. In Proceedings of the 3rd International Symposium on Cone Penetration Testing, Las Vegas, NV, USA, 12-14 May $2014 ;$ pp. 753-759.

32. Kumpiene, J.; Lagerkvist, A.; Maurice, C. Stabilization of As, $\mathrm{Cr}, \mathrm{Cu}, \mathrm{Pb}$ and $\mathrm{Zn}$ in soil using amendments-A review. Waste Manag. 2008, 28, 215-225. [CrossRef]

33. Li, W.; Ni, P.; Yi, Y. Comparison of reactive magnesia, quick lime, and ordinary Portland cement for stabilization/solidification of heavy metal-contaminated soils. Sci. Total Environ. 2019, 671, 741-753. [CrossRef]

34. Reginald, B.; Kogbara, A.A.-T.; Yi, Y.; Stegeman, J.A. Cement-fly ash stabilisation/solidification of contaminated soil: Performance properties and initiation of operating envelopes. Appl. Geochem. 2013, 33, 64-75.

35. Liang, X.; Zang, Y.; Xu, Y.; Tan, X.; Hou, W.; Wang, L.; Sun, Y. Sorption of metal cations on layered double hydroxides. Colloids Surf. A Physicochem. Eng. Asp. 2013, 433, 122-131. [CrossRef]

36. Oti, J.E.; Bai, J. Developing unfired stabilised building materials in the UK. In Engineering Sustainability; ICE Publishing: London, UK, 2008; pp. 211-218. [CrossRef]

37. Niu, M.; Li, G.; Wang, Y.; Li, Q.; Han, L.; Song, Z. Comparative study of immobilization and mechanical properties of sulfoaluminate cement and ordinary Portland cement with different heavy metals. Constr. Build. Mater. 2018, 193, 332-343. [CrossRef]

38. Nidzam, R.M.; Kinuthia, J.M. Sustainable soil stabilisation with blastfurnace slag-A review. Proc. Inst. Civ. Eng. Constr. Mater. 2010, 163, 157-165. [CrossRef]

39. Pu, H.; Mastoi, A.K.; Chen, X.; Song, D.; Qiu, J.; Yang, P. An integrated method for the rapid dewatering and solidification/stabilization of dredged contaminated sediment with a high water content. Front. Environ. Sci. Eng. 2021, 15, 1-12. [CrossRef]

40. Arulrajah, A.; Yaghoubi, M.; Miri, M. ScienceDirect Evaluation of fly ash- and slag-based geopolymers for the improvement of a soft marine clay by deep soil mixing. Soils Found. 2018, 58, 1358-1370. [CrossRef] 